\title{
Isolation, identification, and characterization of Listeria spp. from various animal origin foods
}

\author{
Deepti N. Nayak ${ }^{1}$, C. V. Savalia ${ }^{1}$, I. H. Kalyani ${ }^{2}$, Rajeev Kumar ${ }^{1}$ and D. P. Kshirsagar ${ }^{1}$
}

1. Department of Veterinary Public Health and Epidemiology, Vanbandhu College of Veterinary Science and Animal Husbandry, Navsari Agricultural University, Navsari - 396 450, Gujarat, India; 2. Department of Veterinary Microbiology, Vanbandhu College of Veterinary Science and Animal Husbandry, Navsari Agricultural University, Navsari - 396450 , Gujarat, India.

Corresponding author: Deepti N. Nayak, e-mail: drdeeptin@rediffmail.com, CVS: cv_vet@rediffmail.com, IHK: ihkvet@gmail.com, RK: rajeevkumar@nau.in,DPK: drdpk04v@gmail.com

Received: 21-11-2014, Revised: 15-04-2015, Accepted: 25-04-2015, Published online: 06-06-2015

doi: 10.14202/vetworld.2015.695-701 How to cite this article: Nayak DN, Savalia CV, Kalyani IH, Kumar R, Kshirsagar DP (2015) Isolation, identification, and characterization of Listeria spp. from various animal origin foods, Veterinary World 8(6): 695-701.

\begin{abstract}
Aim: The present study was undertaken with the prime objective of isolating and identifying Listeria spp. from various foods of animal origin sold at retail market outlets in the city of Navsari, Gujarat.

Materials and Methods: Total 200 samples comprising of milk, milk products, meat, and fish (50 each) collected aseptically from local market which were subjected first to pre-enrichment in half strength Fraser broth followed by enrichment in full strength Fraser broth and subsequent plating on PALCAM agar. The growth with the typical colony characteristics were further identified up to species level on the basis of their morphological and biochemical characteristics. Cultures identified as Listeria monocytogenes were further subjected to in vitro pathogenicity tests and detection of different virulenceassociated genes viz. act $\mathrm{A}, h l y \mathrm{~A}$, and iap using polymerase chain reaction.

Results: Of the total 200 food samples of animal origin; $18(9 \%)$ were found positive for Listeria spp. which were identified as Listeria seeligeri (6, 33.3\%), Listeria innocua (5, 27.7\%), Listeria welshimeri (4, 22.2\%), and L. monocytogenes (3, 16.6\%). The highest prevalence was observed in milk samples (8). Species wise, 6 isolates of $L$. seeligeri which included two each from cow milk, buffalo milk, and meat samples; 5 L. innocua isolates included four recovered from fish and one from meat sample; 4 L. welshimeri comprised of two isolates from ice cream and one each from buffalo milk and meat sample; and 3 isolates of L. monocytogenes recovered from milk ( 1 cow and 2 buffalo milk). All 3 L. monocytogenes isolates screened for the presence of virulence genes viz. act A, hlyA, and iap using the specific primers revealed the presence of all the genes suggesting the possibility of danger of foodborne listeriosis among raw milk consumers.

Conclusion: Listeria spp. was isolated from 9\% (18/200) of the animal origin food samples viz.; milk, milk products, meat, and fish with the highest prevalence in the milk samples. L. monocytogenes was isolated from 3 milk samples only. L. seeligeri was the predominant species isolated followed by L. innocua, L. welshimeri, and L. monocytogenes in this study. L. monocytogenes were found to carry virulence genes like actA, hly $A$, and iap genes suggesting the pathogenic potential of these isolates.
\end{abstract}

Keywords: animal origin foods, Listeria monocytogenes, Listeria spp., polymerase chain reaction, virulence genes.

\section{Introduction}

The organisms of genus Listeria are Grampositive, facultative anaerobic, non-spore-forming, rod-shaped bacteria with a low $\mathrm{G}+\mathrm{C}$ content. The genus consists of different species viz.; Listeria monocytogenes, Listeria ivanovii, Listeria seeligeri, Listeria innocua, Listeria welshimeri, Listeria grayi, Listeria marthii, Listeria rocourtiae, as well as newly described non-pathogenic Listeria aquatica spp. nov., Listeria floridensis spp. nov., Listeria cornellensis spp. nov., Listeria grandensis spp. nov., and Listeria riparia spp. nov. [1-3]. L. monocytogenes is a primary human pathogen amidst rare reports of illnesses caused by L. seeligeri, L. ivanovii, and L. innocua [4].

Copyright: The authors. This article is an open access article licensed under the terms of the Creative Commons Attributin License (http:// creative commons.org/licenses/by/2.0) which permits unrestricted use, distribution and reproduction in any medium, provided the work is properly cited.
L. monocytogenes causes gastroenteritis varying from mild to severe illness reported in veterinarians, farmers and abattoir workers; and circling disease which is a manifestation of basilar meningitis besides spontaneous abortions in animals. The pathogen is transmitted via fecal-oral route directly from animals to humans. Vertical transmission from mother to neonate occurs transplacentally or through an infected birth canal. The fatality ranges from $30 \%$ to $75 \%$ especially in high risk groups like pregnant women, unborn or newly delivered infants, and the elderly people as well as persons with severe underlying disease conditions like immune-suppression, AIDS, chronic conditions like cirrhosis $[5,6]$. This organism is halotolerant, and can grow and multiply at refrigeration temperatures [7].

Though not phenomenal, the number of human Listeriosis cases in India, have been in the rise with reports on sporadic cases and incidence in clinical samples and has been quoted as an emerging 
foodborne disease in India by Chugh [8]. Similarly, reports have also been made by Aurora et al. $[9,10]$ on the incidence of $L$. monocytogenes in milk based ready-to-eat foods from Agra region.

Two of the most widely-used culture reference methods for detection of Listeria in all foods are the FDA Bacteriological and Analytical Method (BAM) [11] and the International Organization for Standardization method [12]. Molecular approaches for DNA isolation and identification such as the polymerase chain reaction (PCR) have shown to be faster and more reliable than conventional techniques.

Various foods have been implicated in the spread of L. monocytogenes repeatedly found in raw milk, soft cheese, and pasteurized dairy products including ice cream, fish and fish products, and ready-to eat foods [13-15]. Taking into consideration all these aspects, this study was conducted to study the prevalence of Listeria spp. in foods of animal origin viz.; milk, milk products, meat, and fish samples.

\section{Materials and Methods}

\section{Ethical approval}

Ethical approval is not required to pursue this type of study.

\section{Sample collection}

A total of 200 food samples, comprising of milk (50), ice cream (20), milkshake (15), fruit salad (15), and 50 samples each of fish and meat were collected from randomly selected retail shops of Navsari city. Almost all the ice cream shops from different areas were covered, milk samples were collected from tabelas as well as vendors and fish and meat samples were collected from vendors as well as market. The samples were collected only once from each place. Samples were collected in icebox and stored at $4{ }^{\circ} \mathrm{C}$ till further analysis attempted in the Department of Veterinary Public Health and Epidemiology, Vanbandhu Veterinary College, Navsari Agricultural University, Navsari.

\section{Standard strains}

The standard strains of L. monocytogenes (MTCC 1143), Rhodococcus equi (MTCC 1135), and Staphylococcus aureus (MTCC 3160) used in the study were procured from the Microbial Type Culture Collection and Gene Bank, Institute of Microbial Technology, Chandigarh (IMTC), India.

\section{Isolation and identification of Listeria spp.}

ISO 11290 method was employed to isolate the organisms, whereby pre-enrichment of $25 \mathrm{~g}$ sample was done in $225 \mathrm{ml}$ half strength Fraser broth containing selective supplements (HiMedia) for $24 \mathrm{~h}$ at $30^{\circ} \mathrm{C}$, which was followed by second enrichment of $0.1 \mathrm{ml}$ of pre-enriched Fraser broth content in $10 \mathrm{ml}$ full strength Fraser broth containing selective supplements (HiMedia) for $48 \mathrm{~h}$ at $37^{\circ} \mathrm{C}$ incubation temperature. After the enrichment procedure, the inoculum was plated on PALCAM agar (HiMedia) and incubated for $48 \mathrm{~h}$ at $37^{\circ} \mathrm{C}$.

The gray-green colonies surrounded by diffuse black zone on PALCAM agar were picked up and further purified on Tryptone Soya Yeast Extract agar (TSYEA). Subsequently, pinpoint colonies of TSYEA were subjected to identification procedures which included Gram's staining followed by a microscopic examination, catalase test, and oxidase test. The characteristic Gram-positive, coccobacillary or short rodshaped organisms which were catalase positive and oxidase negative, were sub-cultured in Brain heart infusion (BHI) broth at $25^{\circ} \mathrm{C}$ for $12-18 \mathrm{~h}$. Subsequently, the cultures showing typical tumbling motility were considered as "presumptive" listeria isolates, which were in turn subjected to detailed biochemical tests viz.; methyl red, Voges-Proskauer, nitrate, and sugar fermentation tests with xylose, rhamnose, mannitol, and $\alpha$-methyl D-mannopyranoside as described in Table-1.

\section{In vitro pathogenicity tests}

The isolates were tested for the type and the degree of hemolysis on 5\% sheep blood agar and the Christie Atkins Munch Peterson (CAMP) test was conducted using Listeria isolates, $S$. aureus, and $R$. equi standard strains to observe for hemolysis between Listerial strain and the $S$. aureus or $R$. equi owing to the synergistic effect of their hemolysins in case of a CAMP-positive reaction as indicated in Table-1.

\section{DNA extraction protocol}

The DNA of the L. monocytogenes was extracted using the protocol of QAIGEN DNeasy blood and tissue kit with minor modification in centrifugation parameters that is doubling the time of centrifugation. A loop full of culture grown overnight in $4 \mathrm{ml} \mathrm{BHI}$ broth at $37^{\circ} \mathrm{C}$ was used to isolate the DNA.

\section{Detection of virulent genes}

The L. monocytogenes isolates were screened for the presence or absence of virulence-associated gene(s) by using the standard PCR protocols for the detection of act $\mathrm{A}, h l y \mathrm{~A}$, and iap genes as per the methodology described previously $[15,16]$. Primers used for PCR reaction are mentioned in Table-2 [1519]. The PCR protocol was standardized using $L$. monocytogenes (MTCC 1143). Initial denaturation was carried out at $95^{\circ} \mathrm{C}$ for 2 min followed by denaturation $95^{\circ} \mathrm{C}$ for $15 \mathrm{~s}$ followed by annealing $60^{\circ} \mathrm{C}$ for $30 \mathrm{~s}$ and extension at $72^{\circ} \mathrm{C}$ for $1 \mathrm{~min} 30 \mathrm{~s}$ and repeated for 35 cycles.

\section{Agarose gel electrophoresis protocol}

For PCR amplification, $5 \mu \mathrm{l}$ of the PCR products was mixed with $1 \mu \mathrm{l}$ of $\times 6$ gel loading buffer and electrophoresed along with DNA molecular weight marker (3B BlackBio Biotech) on 2.0\% agarose gel containing ethidium bromide (@ $0.5 \mu \mathrm{g} / \mathrm{ml}$ ) at $5 \mathrm{~V} / \mathrm{cm}$ for $60 \mathrm{~min}$ in $0.5 \times$ tris-borate-ethylenediaminetetraacetic acid buffer. The amplified product was visualized as 
Table-1: Biochemical test pattern and in-vitro pathogenicity profile of the Listeria spp.

\begin{tabular}{|c|c|c|c|c|c|c|c|c|c|c|c|}
\hline \multirow{2}{*}{$\begin{array}{l}\text { Species } \\
\text { identified }\end{array}$} & \multicolumn{5}{|c|}{ Biochemical tests } & \multicolumn{4}{|c|}{ Sugar fermentation pattern } & \multirow{2}{*}{$\begin{array}{l}\text { Hemolysis } \\
\text { on } 5 \% \text { SBA }\end{array}$} & \multirow{2}{*}{$\begin{array}{c}\text { CAMP test with } S \text {. aureus (S) } \\
\text { and } R \text {. equi (R) }\end{array}$} \\
\hline & $\mathbf{C}$ & $\mathbf{0}$ & MR & VP & $\mathbf{N i}$ & L-Rh & D-Xy & aMdm & D-Ma & & \\
\hline L. monocytogenes & + & - & + & + & - & + & - & + & - & + & $+(S)$ \\
\hline L. seeligeri & + & - & + & + & - & - & - & - & - & + & - \\
\hline L. welshimeri & + & - & + & + & - & + & + & + & - & - & - \\
\hline L. innocua & + & - & + & + & - & + & - & + & - & - & - \\
\hline
\end{tabular}

$\mathrm{C}=$ Catalase, $\mathrm{O}=$ Oxidase, $\mathrm{Ni}=$ Nitrate, $\mathrm{L}-\mathrm{Rh}=$ Rhamnose, $\mathrm{D}-\mathrm{Xy}=$ Xylose, aMdm=a-Methyl-d-mannoside, $\mathrm{D}-\mathrm{Ma}=\mathrm{Mannitol}$,

L. monocytogenes =Listeria monocytogenes, L. seeligeri=Listeria seeligeri, L. welshimeri=Listeria welshimeri,

L. innocua =Listeria innocua, SBA =Sheep blood agar, CAMP $=$ Christie Atkins Munch Peterson, MR=Methyl red, VP=Voges

Proskauer

Table-2: Primers used for PCR reaction.

\begin{tabular}{|c|c|c|c|}
\hline Gene & Primer sequence & Base pairs & Reference \\
\hline $\operatorname{act} \mathrm{A}$ & $\begin{array}{l}\text { F: CGC CGC GGA } \\
\text { AAT TAA AAA AAG } \\
\text { R: ACG AAG GAA } \\
\text { CCG GGC TGC TAG }\end{array}$ & 839 & {$[15]$} \\
\hline hlyA & $\begin{array}{l}\text { F: GCA GTT GCA AGC } \\
\text { GCT TGG AGT GAA } \\
\text { R: GCA ACG TAT CCT } \\
\text { CCA GAG TGA TCG }\end{array}$ & 456 & {$[16,18,19]$} \\
\hline iap & $\begin{array}{l}\text { F: ACA AGC TGC } \\
\text { ACC TGT TGC AG } \\
\text { R: TGA CAG CGT } \\
\text { GTG TAG TAG CA }\end{array}$ & 131 & [17] \\
\hline
\end{tabular}

$\mathrm{PCR}=$ Polymerase chain reaction

a single compact band of expected size under UV light and documented by gel documentation system (SynGene, Gene Genius BioImaging System, UK).

\section{Result}

Of 200 samples, total 18 (9\%) food samples were found positive for Listeria spp. The food sample wise, maximum prevalence was noticed in milk samples $(8 / 50,16 \%)$ followed by $8 \%(4 / 50)$ each, of meat and fish samples, and $4 \%$ in milk products $(2 / 50)$. The species wise spread was expressed as maximum 6 cultures $(3 \%)$ of $L$. seeligeri followed in descending rate of occurrence as $5(2.5 \%)$ of L. innocua, $4(2 \%)$, L. welshimeri, and $3(1.5 \%)$ isolates of L. monocytogenes.

Of 6 L. seeligeri isolates, two each were recovered from cow as well as buffalo milk ( $8 \%$ on type of milk basis), and 2 (4\%) from meat samples. Of total 5 isolates of $L$. innocua, $4(8 \%)$ were cultured from fish samples and $1(2 \%)$ from the meat. L. welshimeri (4) isolated from 2 of $20(10 \%)$ ice cream samples and one each, from 25 buffalo milk (4\%) and 50 meat (2\%) samples. A potent pathogen L. monocytogenes was isolated from 3 milk samples $(1.5 \%)$ only, which included $2(8 \%)$ buffalo milk and $1(4 \%)$ cow milk samples as described in Table-3.

All three L. monocytogenes isolates cultured from animal origin food samples, which were subjected for detection of virulence-associated gene studies by PCR yielded desired amplification of $839 \mathrm{bp}$ of act A (Figure-1), $456 \mathrm{bp}$ of hlyA (Figure-2) and $131 \mathrm{bp}$ of iap (Figure-3) genes, respectively.

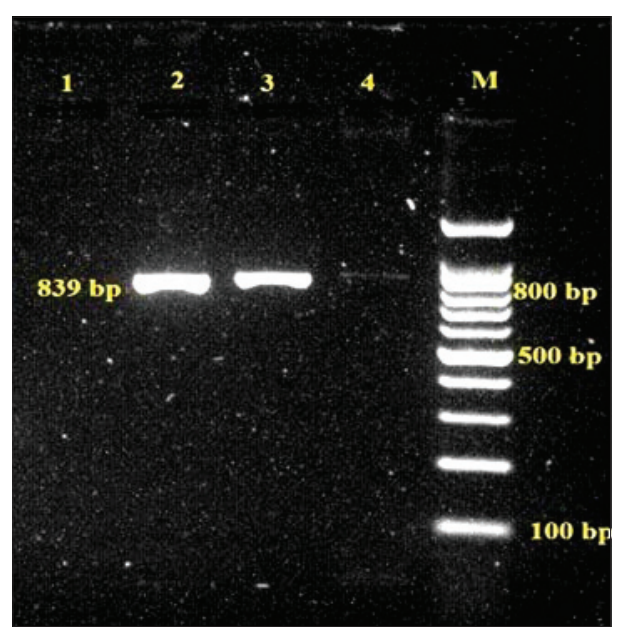

Figure-1: Agarose gel showing polymerase chain reaction amplified product of 839 bp for actA gene in L. monocytogenes isolates, Lane 1: Negative control, Lane 2: Positive control, Lane 3-4: Samples positive for actA, Lane M: 100 bp DNA ladder.

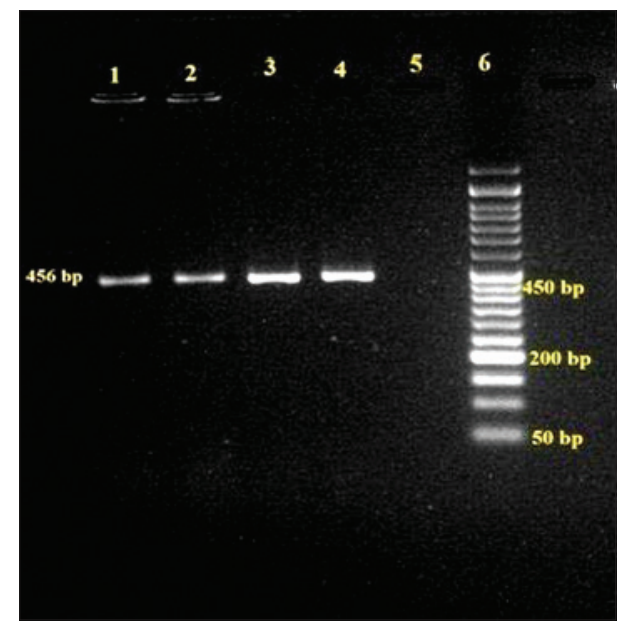

Figure-2: Agarose gel showing polymerase chain reaction amplified product of 456 bp for hlyA gene in L. monocytogenes isolates, Lane 1-3: Samples positive for hlyA, Lane 4: Positive control, Lane 5: Negative control, Lane 6: 50 bp DNA ladder.

\section{Discussion}

\section{Overall prevalence}

The findings of overall prevalence of $9 \%$ Listeria spp. were relatively lower than the earlier findings viz.; $12.5 \%$ from 530 samples of dairy products, meat and RTE foods [20], 16\% of 1481 food samples [21], $38.1 \%$ of 134 food samples [22]. These values are 
Table-3: Prevalence of Listeria spp. in various food samples of animal origin.

\begin{tabular}{|c|c|c|c|c|c|c|}
\hline \multirow{2}{*}{$\begin{array}{l}\text { Type of } \\
\text { sample }\end{array}$} & \multirow{2}{*}{$\begin{array}{c}\text { Number of } \\
\text { samples analyzed }\end{array}$} & \multicolumn{4}{|c|}{ Number of samples positive for Listeria spp. (\%) } & \multirow{2}{*}{$\begin{array}{l}\text { Total positive } \\
\text { samples }\end{array}$} \\
\hline & & L. monocytogenes & L. seeligeri & L. innocua & L. welshimeri & \\
\hline Cow milk & 25 & $1(4)$ & $2(8)$ & 0 & 0 & $3(12)$ \\
\hline Buffalo milk & 25 & $2(8)$ & $2(8)$ & 0 & $1(4)$ & $5(20)$ \\
\hline Total & $M=50$ & $3 / 50(6)$ & $4 / 50(8)$ & 0 & $1 / 50(2)$ & $8 / 50(16)$ \\
\hline Ice cream & 20 & 0 & 0 & 0 & $2(10)$ & $2(10)$ \\
\hline Milkshake & 15 & 0 & 0 & 0 & 0 & 0 \\
\hline Fruit salad & 15 & 0 & 0 & 0 & 0 & 0 \\
\hline Total & $M P=50$ & 0 & 0 & 0 & $2 / 50(4)$ & $2 / 50(4)$ \\
\hline Meat & 50 & 0 & $2(4)$ & $1(2)$ & $1(2)$ & $4(8)$ \\
\hline Fish & 50 & 0 & 0 & $4(8)$ & 0 & $4(8)$ \\
\hline Total & 200 & $3(1.5)$ & $6(3)$ & $5(2.5)$ & $4(2)$ & $18(9)$ \\
\hline
\end{tabular}

$\mathrm{M}=$ Milk, MP=Milk product, L. monocytogenes=Listeria monocytogenes, L. seeligeri=Listeria seeligeri,

L. welshimeri=Listeria welshimeri, L. innocua =Listeria innocua

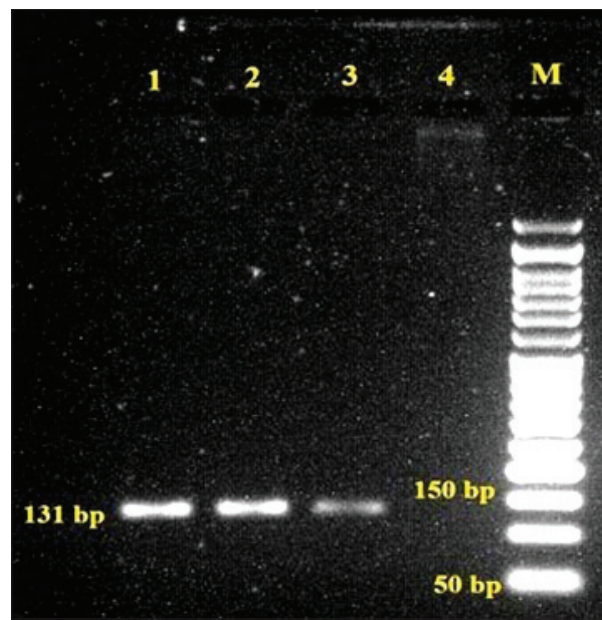

Figure-3: Agarose gel showing polymerase chain reaction amplified product of 131 bp for iap gene in L. monocytogenes isolates, Lane 1-2: Samples positive for iap, Lane 3: Positive control, Lane 4: Negative control, Lane $\mathrm{M}$ : 50 bp DNA ladder.

higher than those observed in our study might be due to variation in the place of work.

In the present study, L. monocytogenes was isolated from $3(1.5 \%)$ food samples only, none other than milk $(3 / 50,6 \%)$. Earlier studies reported occurrence of this pathogen in varying levels on overall basis, viz.; $17.5 \%$ among 320 samples of different vegetables, meat, sea foods, and dairy products [22], $7.9 \%$ of 1537 beef, pork, chicken, fish, raw milk, ice cream samples [23] and 3.5\% (8/225) milk, cheese, chicken, and red meat specimens [24] which is quite higher than present findings. This variation in the findings may be due to disparity in the type of foods considered in the present work, and number of samples analyzed.

\section{Sample wise prevalence}

According to the type of milk, $12 \%(3 / 25)$ cow milk and 20\% (5/25) buffalo milk samples contained Listeria spp., with an overall prevalence of $16 \%$ in 50 milk samples. Compared to the present study quite higher prevalence of Listeria spp. in milk was observed as $21.32 \%$ [25], 22\% [26], 26.13\% [27], and $54.7 \%$ [28]. Although source of the bacteria the milk samples in the present work is obscure, work reviewed indicated that Listeria spp. do isolated from rotting vegetation, soil, and water. In contrast, lower level of prevalence was reported in the earlier observations made by Yoshida et al., [29] as $0.3 \%$ by Bhilegaonkar et al. as $5.78 \%$ [30], by Gulhan et al. as 6\% [31], by Kalorey et al. as $6.75 \%$ [32], by Moura et al. [33] as $6.8 \%$, and by Alzubaidy et al. [24] who observed 9\% incidence of Listeria spp. in raw milk samples, indicative of lower level of contamination, might be due to good hygienic practices in the places from where samples drawn. The prevalence of $L$. monocytogenes detected from milk samples in this study was $6 \%$ which is in congruence to $5.78 \%$ [30] prevalence of L. monocytogenes in farm and bulk milk samples as well as with $6.25 \%$ milk samples out of 64 analyzed by Barbuddhe et al. [27]. The prevalence values are also comparable to $6.5 \%$ obtained from 861 milk samples [34] as well as $5.88 \%$ prevalence of $L$. monocytogenes reported from raw milk samples by Waghmare [25] but lower than 19.6\% observed by Molla et al. [35]. Out of 137 milk samples analyzed by Sarangi et al. [36] four (2.91\%) L. monocytogenes, three (2.18\%) L. innocua, and two $(1.45 \%)$ L. welshimeri were isolated which is lower than that observed in the present study.

Examination of 50 milk product samples comprising of 20 ice cream, 15 milkshake, and 15 fruit salad samples revealed the presence of Listeria spp. in $10 \%$ ice cream samples only identified as L. welshimeri. The prevalence of Listeria spp. in ice cream, i.e. $4 \%$ in the present study was much lower as compared to those observed by various workers as $43.5 \%$ out of 137 ice cream samples analyzed [33], 41.7\% Listeria spp. in ice cream from 134 food samples analyzed [14], 16.7\% in ice-cream from 290 samples of traditional milk products in Iran [13] thereby demanding care in preparation of the milk product to protect health of consumers. Comparatively lower degrees of incidence have been recorded in ice cream samples viz.; 5\% [37], 6\% [38] and 6.1\% [23], respectively; which is indicative of marginally safe food hygiene practices might have followed at places under the 
studies.

The present study indicated that out of 50 meat samples surveyed, 8\% (4/50) samples yielded growth of Listeria spp. The findings are in approximation with earlier reports of Barbuddhe et al. [27] as $10.17 \%$ of 167 meat samples positive for Listeria spp. as well as $6.7 \%$ positivity of Listeriae among 150 meat samples screened denoted by Nayak et al. [39]. Values of prevalence of Listeria spp. in meat samples obtained as 50\% [14], 27.2\% [20] and 22\% [24] were higher than the present study provided warning signal for safeguarding human health as far as usage of meat as food is concerned. None of 50 meat samples examined during the present investigation yielded L. monocytogenes.

All the four fish isolates recovered in the present investigation were identified as L. innocua. Literature reviewed showed comparatively high prevalence in seafood samples, viz.; by Murtiningsih and Sunarya [40] who tested 124 fish and seafood samples, wherein L. innocua was identified as dominant species cultured from $11.3 \%$ samples, $17.5 \%$ prevalence of $L$. innocua and L. monocytogenes reported in Mangalore India [22], 32.3\% samples out of 324 tropical seafood and environmental samples positive for Listeria spp. with $L$. innocua as most prevalent bacteria of fisheries from Kerala, India [41] are in resemblance to the present study. But in contrast, L. innocua was isolated from $0.9 \%$ samples of the 300 marine food samples analyzed by Momtaz et al. [42]. The prevalence of Listeria spp. in the present investigation turned out to be $8 \%$ expressed on the basis of 50 fish samples surveyed, which is in agreement with finding of Swetha et al. [43] who found 8\% level of isolation of Listeria spp. in 60 fish samples from Hyderabad, India.

However, higher values than present work were detected during studies conducted by Ghazi M. Jabir Al-Maliki [44] and Wang et al. [45] who isolated Listeria spp. from 13 and 13.8\% fish and seafood samples, respectively. On the other hand, values lower than the present study were also observed as $1.2 \%$ from shellfish [23] and 5\% dry fish [41].

A desired amplified product of $839 \mathrm{bp}$ similar to the reference strain, sequenced for actA gene was present in all the L. monocytogenes isolates. Earlier studies also cited actA gene in L. monocytogenes recovered from fish and marine food samples [16,41,42]. Only two of the three isolates identified as L. monocytogenes in the present work amplified $131 \mathrm{bp}$ product in lieu to the reference strain with the use of primer pair synthesized for iap gene which is in parallel to the findings of Jallewar et al. [16] wherein iap gene was detected in L. monocytogenes as well as L. seeligeri from fish samples, from ice-cream samples [36], from fish samples [41], and from milk, water, and human clinical samples [46]. All the 3 isolates yielded desired amplified product of approximately $456 \mathrm{bp}$, similar to the reference strain of $L$. monocytogenes using the primer pair for $h l y \mathrm{~A}$ which encodes pore-forming listeriolysin
O necessary for bacterial escape from the phagosomes of host cells into the host cytosol. The characterization of L. monocytogenes was studied and isolates were confirmed by PCR amplification of $h l y$ virulence gene from various foods [23], fish samples [16,41], and milk samples [32].

\section{Conclusions}

Listeria spp. was isolated from 9\% (18/200) of the samples of animal origin foods which included milk, milk products, meat, and fish with highest prevalence from milk samples. L. monocytogenes was isolated from 3 milk samples only. Among all L. seeligeri was the predominant species isolated followed by L. innocua, L. welshimeri, and L. monocytogenes in this study. All three L. monocytogenes isolates showed the presence of actA and hlyA whereas only two isolates amplified iap virulence genes.

\section{Authors' Contributions}

CVS designed and monitored the study. DNN and DPK collected references, samples, and performed laboratory investigation. CVS, IHK, DNN, and RK drafted and revised the manuscript. All authors read and approved the final manuscript.

\section{Acknowledgments}

Financial and technical support rendered by Navsari Agricultural University, as well as Vanbandhu Veterinary College, Navsari is duly acknowledged.

\section{Competing Interests}

The authors declare that they have no competing of interests.

\section{References}

1. Graves, L.M., Hesel, S.O., Steigerwalt, A.G., Morey, R.E. and Daneshvar, M.I. (2010) Listeria marthii isolated from the natural environment, Finger Lakes National Forest. Int. J. Syst. Evol. Microbiol., 60: 1280-1288.

2. Jeyaletchumi, P., Tunung, R., Margaret, S., Son, R., Farinazleen, M. and Cheah, Y. (2010) Detection of Listeria monocytogenes in foods. Int. Food. Res. J., 17: 1-11.

3. den Bakker, H.C., Warchocki, S., Wright, E.M., Allred, A.F., Ahlstrom, C., Manuel, C.S., Stasiewicz, M.J., Burrell, A., Roof, S., Strawn, L.K., Fortes, E., Nightingale, K.K., Kephart, D. and Wiedmann, M. (2014) Listeria floridensis sp. nov., Listeria aquatica sp. nov., Listeria cornellensis sp. nov., Listeria riparia sp. nov. and Listeria grandensis sp. nov., from agricultural and natural environments. Int. J. Syst. Evol. Microbiol., 64: 1882-1889.

4. Perrin, M., Bremer, M. and Delamare, C. (2003) Fatal cases of Listeria innocua bacteria. J. Clin. Microbiol., 41: 5308-5309

5. Liu, D. (2006) Identification, subtyping and virulence determination of Listeria monocytogenes, an important foodborne pathogen. J. Med. Microbiol., 55: 645-659.

6. Mead, P.S., Slutsker, L., Dietz, V., McCaig, L. and Bresee, J. (2010) Food related illness and death in the United States. Emerg. Infact. Dis., 5: 607-625.

7. Dillon, R.M. and Patel, T.R. (1992) Listeria in seafood: A review. J. Food Prot., 55: 1009-1015.

8. Chugh, T.D. (2008) Emerging and re-emerging bacterial diseases in India. J. Biosci., 4: 549-555.

9. Aurora, R., Prakash, A. and Prakash, S. (2006) Occurrence 
of pathogenic Listeria monocytogenes in raw milk and ready-to-eat milk products in Agra city, India. Indian $J$. Comp. Microbiol. Immunol. Infect. Dis., 27: 87-93.

10. Aurora, R., Prakash, A. and Sant, P. (2009) Genotypic characterization of Listeria monocytogenes isolated from milk and ready-to-eat indigenous milk products. Food Control, 9: 835-839.

11. Hitchins, A.D. (2001) Listeria monocytogenes: US Food and Drug Administration. Bacteriological Analytical Manual. Available from: http://www.fda.gov/food/food science research/laboratory methods/ucm2006949.htm accessed on 11-09-2014.

12. ISO. (2004) Microbiology of food and animal feeding stuffs - Horizontal method for the detection and enumeration of Listeria monocytogenes - Part 1: Detection method. International Standard ISO 11290-1, AMENDMENT 1: Modification of the isolation media and the haemolysis test, and inclusion of precision data, Geneva, Switzerland.

13. Rahimi, H., Momtaz, A., Sharifzadeh, A., Behzadnia, A., Ashtari, M.S., Esfahani, S.Z., Riahi, M. and Momeni, M. (2012) Prevalence and antimicrobial resistance of Listeria species isolated from traditional dairy products in Chahar Mahal and Bakhtiyari, Iran. Bulg. J. Vet. Med., 15(2): 115-122.

14. Shrinithivihahshini, N., Mariyaselvam, S., Duraisamy, M. and Rengaraj, C. (2011) Occurrence of Listeria monocytogenes in food and ready to eat food products available in Tiruchirappalli, Tamil Nadu, India. World J. Life. Sci. Med. Res., 1: 70-75.

15. Jaradat, Z.W., Schutze, G.E. and Bhunia, A.K (2002) Genetic homogeneity among Listeria monocytogenes strains from infected patients and meat products from two geographic locations determined by phenotyping, ribotyping and PCR analysis of virulence genes. Int. J. Food Microbiol., 76: 1-10.

16. Jallewar, P.K., Kalorey, D.R., Kurkure, N.V., Pande, V.V. and Barbuddhe, S.B. (2007) Genotypic characterization of Listeria spp. Isolated from fresh water fish. Int. J. Food Microbiol., 114: 120-123.

17. Vázquez-Boland, J.A., Domínguez-Bernal, G., GonzálezZorn, B., Kreft, J. and Goebel, W. (2001) Pathogenicity islands and virulence evolution in Listeria. Microb. Infect., 3: $571-584$.

18. Furrer, B., Candrian, U., Hoefelein, C. and Luethy, J. (1991) Detection and identification of Listeria monocytogenes in cooked sausage products and in milk by in vitro amplification of haemolysin gene fragments. J. Appl. Bacteriol., 70: 372-379.

19. Paziak-Domanska, B., Boguslawska, E., WiekowskaSzakiel, M., Kotlowski, R., Rozalska, B., Chmiela, M., Kur, J., Dabrowski, W. and Rudnicka, W. (1999) Evaluation of the API test, phosphatidylinositol-specific phospholipase $\mathrm{C}$ activity and PCR method in identification of Listeria monocytogenes in meat foods. FEMS. Microbiol. Lett., 171: 209-214.

20. Akya, A., Najafi, F., Moradi, J., Mohebiand, Z. and Adabagher, S. (2013) Prevalence of food contamination with Listeria spp. in Kermanshah, Islamic Republic of Iran. East. Mediterr. Health J., 19: 474-477.

21. Gallegos, J.M., Vanegas, M.C., Albarracin, Y., Mattar, S., Poutou, R.A. and Carrascal, A.K. (2008) Frequency of isolation of Listeria species in different retail foods in Colombia. Anim. Prod. Res. Adv., 4: 9.

22. Dhanashree, B., Otta, S.K. and Karunasagar, I. (2003) Typing of Listeria monocytogenes isolates by random amplification of polymorphic DNA. Indian J. Med. Res., 117: 19-24.

23. Baek, S.Y., Lim, S.Y., Lee, D.H., Min, K.H. and Kim, C.M. (2000) Incidence and characterization of Listeria monocytogenes from domestic and imported foods in Korea. J. Food Prod., 4: 186-189.

24. Alzubaidy, Z.M., Kakey, S.I. and Jassim, F.A. (2013)
Isolation and identification of Listeria moncytogenes by PCR from some food sources in Erbil city. Euphrates $J$. Agric. Sci., 5(3): 14-26.

25. Waghmare, R.N. (2006) Prevalence and Molecular characterization of Listeria monocytogenes from milk. M.V.Sc. Thesis, MAFSU, Bombay Veterinary College, Mumbai.

26. Sharma, D., Sharma, P.K., Saharan, B.S. and Malik, A. (2012) Isolation, identification and antibiotic susceptibility profiling of antimicrobial resistant Listeria monocytogenes from dairy milk. Int. J. Microbiol. Res. Technol., 1(1): 1-4.

27. Barbuddhe, S.B., Chaudhari, S.P. and Malik, S.V.S. (2002) The occurrence of pathogenic Listeria monocytogenes and antibodies against Listeriolysin-O in buffaloes. J. Vet. Med. B., 49: 181-184.

28. Kellis, J., Gilmour, A. (2004) Incidence of Listeria monocytogenes in two milk processing environments and assessment of Listeria monocytogenes blood agar for isolation. Int. J. Food Microbiol., 91: 167-174.

29. Yoshida, T., Sato, M. and Hirai, K. (1998) Prevalence of Listeria species in raw milk from farm bulk tanks in Nagano prefecture. J. Vet. Med. Sci., 60: 311-314.

30. Bhilegaonkar, K.N., Kulshresta S.B., Kapoor, K.N., Kumar, A., Agarwal R.K. and Singh, B.R. (1997) FAO/ WHO Collaborating centre for research, Izatnagar. Training in Veterinary public health. Vol. 34. Indian Veterinary Research Institute, Izatnagar. 248-250.

31. Gulhan, T., Vardar, U.M. and Zahir, U.M. (1997) Incidence of Listeria spp. from raw milk in Sivas. Truk. J. Med. Sci., 28: 389-392.

32. Kalorey, D.R., Warke, S.R., Kurkure, N.V., Rawool, D.B. and Barbuddhe, S.B. (2008) Listeria species in bovine raw milk: A large survey of Central India. Food Control, 19: 109-112.

33. Moura, S.M., Destro, M.T. and Franco, B.D. (1993) Incidence of Listeria species in raw and pasteurized milk produced in Sao Paulo, Brazil. Int. J. Food Microbiol., 19: 229-237.

34. Van Kessel, J.A., Karns, J.S. and Gorski, L. (2005) Prevalence of Salmonellae, Listeria monocytogenes and fecal coliforms in bulk tank milk on U.S. dairies. J. Dairy Sci., 87(9): 2822-2830.

35. Molla, B., Yilma, R. and Alemayehu, D. (2004) Listeria monocytogenes and other Listeria species in retail meat and milk products in Addis Ababa, Ethiopia. Ethiop. J. Health Dev., 18: 208-212.

36. Sarangi, L.N., Panda, H.K., Priyadarshini, A., Sahoo, S., Palai, T.K., Ranabijuli, S. Senapati, S. and Mohanty, D.N. (2009) Prevalence of Listeria species in milk sample of cattle of Odisha. Immunol. Infect. Dis., 2: 135-136.

37. Moharram, M., Charith Raj, A.P. and Janardhana, G.R. (2007) Prevalence of Listeria monocytogenes in ice creams sold in Mysore city and detection by polymerase chain reaction (PCR). Asian J. Microbiol. Biotechnol. Environ. Sci., 9: $151-154$

38. Wosila, M., Muleta, D., Deneke, Y., Gashaw, A. and Bitew, M. (2013) Studies on occurence of Listeria monocytogenes and other species in milk and milk products in retail market of Jimma Town, Ethiopia. Asian J. Dairy Food Res., 32: 35-39.

39. Nayak, J.B., Brahmbhatt, M.N., Savalia, C.V., Bhong, C.D., Roy, A., Kalyani, I.H. and Parmar, B.C. (2010) Detection and characterization of Listeria species from buffalo meat. Buffalo Bull., 29: 83-87.

40. Murtiningsih, R. E. and Sunarya, H. N. (1998) Incidence of Listeria in Fish and Seafood in Indonesia In: Fish utilization in Asia and the Pacific. Proceedings of the APFIC Symposium, Beijing, China, RAP Publication (FAO). Regional Office for Asia and the Pacific, FAO, Bangkok, Thailand. Asia-Pacific Fishery Commission. p270-276.

41. Das, S., Kuttanappilly, V.L., Thampuran, N. and Poothavallil, K.S. (2012) Isolation and characterization of Listeria monocytogenes from tropical seafood of Kerala, 
India. Ann. Microbiol., 12: 566-569.

42. Momtaz, H., Yadollahi, S., Doudi, M., and Tajbakhsh, E., (2013) Isolation and characterization of Listeria species and determines Listeria monocytogenes serotypes in fresh fish, shrimp, crab and lobster in Isfahan and Shahrekord, Iran. Int. J. Adv. Biol. Biomed. Res., 1: 2322-4827.

43. Swetha, C.S., Madhava, Rao, T., Krishnaiah, N. and Kumar, V. (2012) Detection of Listeria monocytogenes in fish samples by PCR assay. Ann. Biol. Res., 3: 1880-1884.

44. Jabir Al-Maliki, G.M. (2010) Prevalence of Listeria monocytogenes in frozen fish in Basrah city markets. Basrah J. Vet. Res., 10: 127-132.

45. Wang, X.M., Lü, X.F., Yin, L., Liu, H.F., Zhang, W.J., Si, W. and Liu, S.G. (2013) Occurrence and antimicrobial susceptibility of Listeria monocytogenes isolates from retail raw foods. Food Control, 32: 153-158.

46. Soni, D.K., Singh, R.K., Singh, D.V. and Dubey, S.K. (2013) Characterization of Listeria monocytogenes isolated from Ganges water, human clinical and milk samples at Varanasi, India. Appl. Environ. Microbiol., 68: 6273-6282.

$* * * * * * * *$ 